\title{
A father collaborates with a research professor to tell the father's story. What could we ALL have done better? Donald looks back at his daughter's eating disorder
}

\author{
Donald Irvine ${ }^{1 *}$, Michael P Levine ${ }^{2}$ \\ From 2014 ANZAED Conference: Driven Bodies Driven Brains \\ Fremantle, Australia. 22-23 August 2014
}

A Father/Dad/Husband story of a 13 year Eating Disorder (AN) experience, pre-diagnosis, post diagnosis/pre/ post major relapse, into recovery.

A father's story of what is it like to experience a 13 year old caring, loving, bubbly, confident, talented, high/achieving \& intelligent girl starting her teenage years transform into a 16 year old, struggling with feelings \& thoughts, becoming a teenager centred on food intake \& body image with personality changes. As a parent, what does it feel like seeing her talents, intelligence \& bubbliness fade, becoming a 16 year old, physically fading \& having increasing difficulty with school \& studies, \& family/ friends?

In this presentation Donald Irvine with the collaboration of Professor Michael Levine will describe his family's journey \& experiences, including his own, as; (1) his daughter became ill with an eating disorder; (2) as the disorder progressed and enveloped the family, including a significant relapse; and (3) as the family struggled to locate and participate in treatment \& finding recovery.

Donald' will conclude by sharing some of the hardearned lessons \& successes from this ongoing journey, in the hope that his experiences will be of benefit to sufferers, carers, and treatment providers.

This abstract was presented in the Learning from Consumers stream of the 2014 ANZAED Conference.

Authors' details

${ }^{1}$ F.E.A.S.T, Perth, Australia. ${ }^{2}$ Department of Psychology Kenyon College,

Gambier, United States.

\footnotetext{
* Correspondence: dirv2462@bigpond.net.au

${ }^{1}$ F.E.A.S.T, Perth, Australia

Full list of author information is available at the end of the article
}

Published: 24 November 2014

doi:10.1186/2050-2974-2-S1-O52

Cite this article as: Irvine and Levine: A father collaborates with a research professor to tell the father's story. What could we ALL have done better? Donald looks back at his daughter's eating disorder. Journal of Eating Disorders 2014 2(Suppl 1):052.
Submit your next manuscript to BioMed Central and take full advantage of:

- Convenient online submission

- Thorough peer review

- No space constraints or color figure charges

- Immediate publication on acceptance

- Inclusion in PubMed, CAS, Scopus and Google Scholar

- Research which is freely available for redistribution

\section{() Biomed Central}

